\title{
Length-Length and Length-Weight Relationships of Lessepsian Saurida undosquamis from the İskenderun Bay (Eastern Mediterranean, Turkey)
}

\author{
Serdar YEDİER ${ }^{1}$, Seda KONTAŞ ${ }^{2}$, Derya BOSTANCI ${ }^{1 *}$
}

\begin{abstract}
In this study, the length-length and length-weight relationships were investigated for Saurida undosquamis from the Eastern Mediterranean Sea (Turkey). All fish sample lengths and weights were recorded to the nearest $0.01 \mathrm{~g}$ and to $0.01 \mathrm{~cm}$, respectively. According to t-test results, there were statistically significant differences between sexes in terms of length and weight $(P<0.05)$ for $S$. undosquamis; therefore, female and male samples were separately evaluated in the current study. The length-weight relationship equations of $S$. undosquamis were calculated as $\mathrm{W}=0.0023 \mathrm{TL}^{3.330} ; \mathrm{W}=0.0014 \mathrm{TL}^{3.487}$ and $\mathrm{W}=0.0020 \mathrm{TL}^{3.366}$ for females, males, and all individuals, respectively. It was found that the " $b$ " value in the length-weight relationship equation was statistically different from $3(P<0.05)$. As a result of the analysis, it was determined that $S$. undosquamis showed positive allometric growth in this habitat. When the length-length relationships of $S$. undosquamis were examined, they were found that the coefficients of determination ranged from 0.98 to 0.99 and they were also highly significant $(P<0.001)$. This study can help provide the necessary information to ensure the sustainability of fish stocks.
\end{abstract}

Keywords: Lessepsian species, Saurida undosquamis, length-length relationship, length-weight relationship

\section{İskenderun Körfezi'nde (Doğu Akdeniz, Türkiye) Yayılım Gösteren Lesepsisyen Saurida undosquamis Türünün Boy-Boy ve Boy-Ağırlık İlişkileri}

ÖZET: Bu çalışmada, Doğu Akdeniz (Türkiye)'de yayılış gösteren Saurida undosquamis türünün boy-boy ve boy-ağırlık ilişkileri incelenmiştir. Balık örneklerinin boyları ve ağırlıkları sırasıyla $0.01 \mathrm{gr}$ ve $0.01 \mathrm{~cm}$ hassasiyetle kayıt altına alınmıştır. Çalışmamızda $S$. undosquamis türünün boy ve ağırlık değerleri bakımından t-testi sonuçlarına göre cinsiyetler arasında istatistiksel manada bir farklılık olduğu $(P<0.05)$ için dişi ve erkek bireyler ayrı ayrı değerlendirilmiştir. $S$. undosquamis türünün dişi, erkekler ve tüm bireyler için boy-ağırlık ilişkisi denklemleri sırasıyla $\mathrm{W}=0.0023 \mathrm{TL}^{3.330} ; \mathrm{W}=0.0014 \mathrm{TL}^{3.487}$ ve $\mathrm{W}=0.0020 \mathrm{TL}^{3.366}$ olarak hesaplanmıştır. Boy-ağırlık ilişki denklemindeki “ $b$ ” değerinin 3'ten istatistiksel olarak farklı olduğu belirlenmiştir $(P<0.05)$. Yapılan analiz sonucunda, $S$. undosquamis bu habitatta pozitif allometrik bir büyüme gösterdiği belirlenmiştir. S. undosquamis'in boy-boy ilişkileri incelendiğinde belirleme katsayılarının 0.98 ile 0.99 arasında değiştiği ve istatistiksel olarak anlamlı oldukları belirlenmiştir $(P<0.001)$. Bu çalışma balık stoklarının sürdürülebilirliğini sağlamak için gerekli bilginin sağlanmasında yardımcı olabilir.

Anahtar Kelimeler: Lessepsiyen türler, Saurida undosquamis, boy-boy ilişkisi, boy-ağırlık ilişkisi

\footnotetext{
1 Serdar YEDİER (Orcid ID: 0000-0003-0017-3502), Derya BOSTANCI (Orcid ID: 0000-0003-3052-9805), Ordu Üniversitesi, Fen-Edebiyat Fakültesi, Moleküler Biyoloji ve Genetik Bölümü, Ordu, Türkiye

2 Seda KONTAŞ (Orcid ID: 0000-0002-6582-6722), Ordu Üniversitesi, Fatsa Deniz Bilimleri Fakültesi, Balıkçılık Teknolojisi Mühendisliği Bölümü, Ordu, Türkiye

*Sorumlu Yazar/Corresponding Author: Derya BOSTANCI, e-mail: deryabostanci@gmail.com 


\section{INTRODUCTION}

Turkey has very rich marine and freshwater fish fauna because of having different seas such as the Mediterranean Sea, the Black Sea, the Sea of Marmara and the Aegean Sea and also having different inland water habitats. The Mediterranean Sea is one of the marine ecosystems with an exceptionally high rate of fish species and has more than 1000 alien species (Bilecenoğlu et al., 2013). In addition, many fish species migrated from the Red Sea and the Indian Ocean to the Mediterranean Sea through the Suez Canal, which was opened in 1869. These species are named as the lessepsian species. One of these lessepsian species is Brushtooth lizardfish, Saurida undosquamis (Richardson, 1848) (Synodontidae). S. undosquamis is distributed in the northern Java, Red Sea, eastern Indian Ocean, southern Philippines, Malay Peninsula, Arafura Sea, northern half and southwestern Australia and Louisiade Archipelago (Froese and Pauly, 2019). S. undosquamis is among the lessepsian species that scattered over the Eastern Mediterranean coast through the Suez Channel from the Red Sea (Golani, 1998). Brushtooth lizardfish is a demersal fish species and found on the sublittoral zone above $100 \mathrm{~m}$ over mud bottoms or sand of coastal waters. They feed on crustaceans, fishes (red mullet and anchovy), and other invertebrates (Sulak, 1986). The conservation status of $S$. undosquamis is "LC" according to the IUCN Red List. This fish species is economically important and there are several studies such as biology and population dynamics (Rajkumar et al., 2003), feeding and reproductive biology (Kadharsha et al., 2013), growth and mortality (Kalhoro et al., 2014).

The length-weight relationship (LWRs) is very important for fish biology. The length-weight relationship parameters $(a$ and $b$ ) allow to estimate the fish weight from the length, calculate the condition index, compare the morphology and the course of life in different habitats (Petrakis and Stergiou, 1995). Ricker (1975) also stated that length-weight relationships and whether fish growth is allometric or isometric in fisheries studies. There are three different growth types were reported. The growth types are; positive allometric $(b>3)$, isometric $(b=3)$ and negative allometric $(b<3)$.

Some deformations may occur in the caudal fins of the fish species due to several reasons in the own habitat. This makes it difficult to make total length measurements of fish and can cause errors in fishing biology. It can determine the total length of fish by using the relationships between the standard length and total length or fork length and total length. Besides, the comparison of the relationships between different length types (LLRs) in fisheries also plays an important role in growth studies (Froese and Pauly, 1998).

There are many studies conducted about length-length and length-weight relationships in Turkey with both freshwater and marine species. For instance, Cyprinus carpio and Tinca tinca in Hirfanlı Dam Lake (Y1lmaz et al., 2010), Blicca bjoerkna in Lake Ladik (Y1lmaz et al., 2012), Carassius gibelio in Lake Ladik (Yazicioğlu et al., 2013), Squalius cephalus in inland waters of the Middle Black Sea region (Özpiçak et al., 2018), Rhodeus amarus in Samsun inland waters (Saygın et al., 2018), 13 fish species in the Black Sea (Türker and Bal, 2018), Pagellus acarne in the Sea of Marmara (Yedier et al., 2019) and nine Chondrichthyes fish species in Edremit Bay (Türker et al., 2019).

The aim of the present study was to determine the length-length and length-weight relationships for lessepsian Saurida undosquamis from the İskenderun Bay (Eastern Mediterranean, Turkey).

\section{MATERIALS AND METHODS}

$S$. undosquamis samples were obtained as a result of a coordinated study with local fishermen in April 2009. In the current study, İskenderun Bay $\left(36^{\circ} 36^{\prime} 0^{\prime \prime} \mathrm{N}, 36^{\circ} 10^{\prime} 59^{\prime \prime} \mathrm{E}\right)$ was determined as the 
sampling area (Fig. 1). After the fish samples were caught, they were moved to the Hydrobiology laboratory at Ordu University and were saved there until the analysis.

In the analysis process, each fish sample was cleaned, and then their body weight (nearest the $0.01 \mathrm{~g}$ ) and total length (TL), standard length (SL) and fork length (FL) (nearest the $0.01 \mathrm{~cm}$ ) were recorded. $S$. undosquamis samples sexes were determined by macroscopic examination of the gonads.

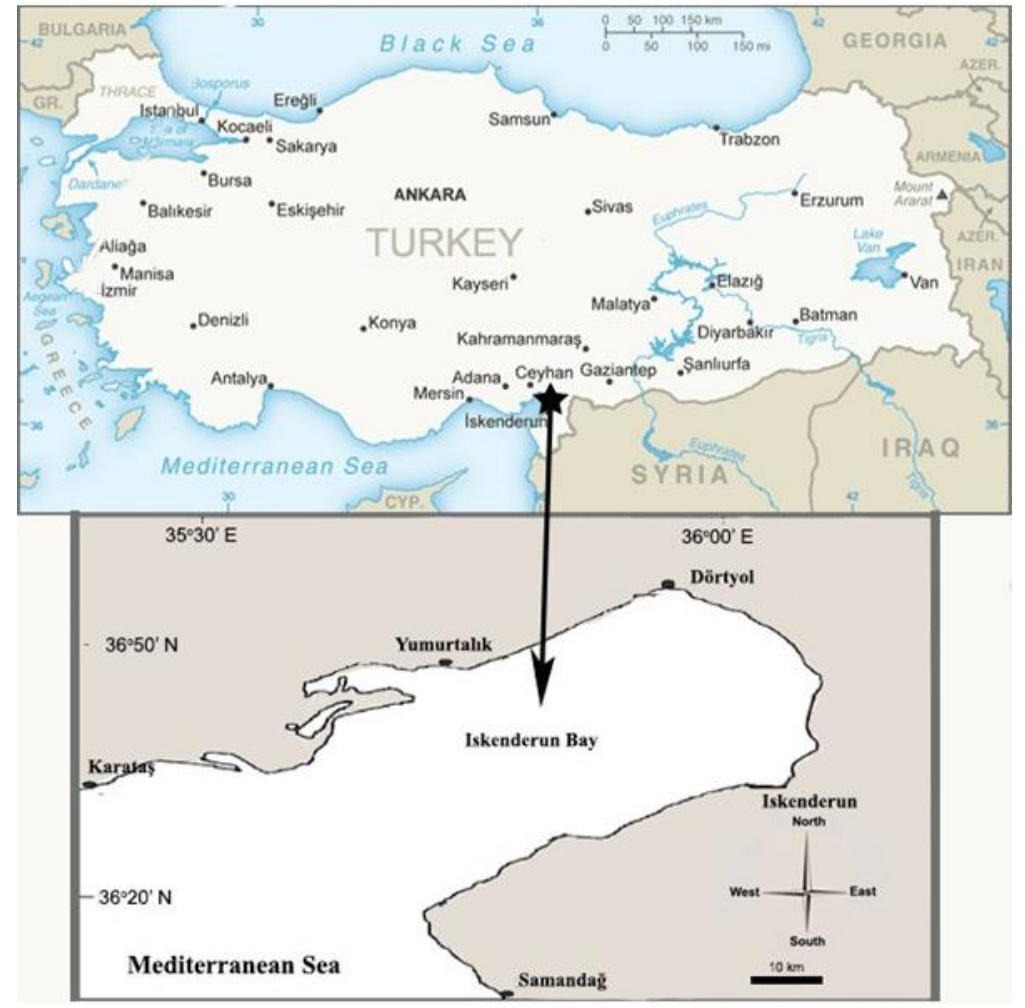

Figure 1. Sampling area.

The length-length relationships (TL-FL, TL-SL, and FL-SL) were determined by using the linear regression model with the equation $\mathrm{y}=\mathrm{a}+\mathrm{bx}$. Length-weight relations were calculated using the equation $\mathrm{W}=\mathrm{aL}^{\mathrm{b}}$, where $\mathrm{L}$ is the total length $(\mathrm{cm}), \mathrm{W}$ is the total weight of the fish $(\mathrm{g}), a$ and $b$ are the parameters of the equation (Bagenal and Tesch, 1978). The t-test was used to test the slopes $(b)$ were significantly different or not. Analysis of variance (ANOVA) was employed to test differences length-weight relationship $b$ values between sexes.

Three different types of length-length relationships were computed using linear regression analysis for the species. TL\&FL, TL\&SL, and FL\&SL relationships were estimated separately for each species. All statistical analyses were tested at the 0.05 significance level using the SPSS 22 program. In the present study, all graphics were created with the Excel software.

\section{RESULTS AND DISCUSSION}

In the current study, a total of 110 brushtooth lizardfish were examined in the Eastern Mediterranean. According to the t-test, there was a statistically important difference between females and males as regards mean length and weight values $(P<0.05)$; therefore, the calculations were performed separately for females, males, and all individuals. The descriptive statistics of brushtooth lizardfish samples were presented in Table 1. 
Length-Length and Length-Weight Relationships of Lessepsian Saurida undosquamis from the İskenderun Bay (Eastern Mediterranean, Turkey)

Table 1. Descriptive statistics of $S$. undosquamis from İskenderun Bay

\begin{tabular}{|c|c|c|c|c|c|c|}
\hline & \multicolumn{3}{|c|}{ Total Length (cm) } & \multicolumn{3}{|c|}{ Weight (g) } \\
\hline & q & $\pi$ & 90 & q & $\hat{0}$ & qर्र \\
\hline Mean \pm S.E. & $25.49 \pm 0.517$ & $22.18 \pm 0.378$ & $23.6 \pm 0.358$ & $115.42 \pm 8.01$ & $73.62 \pm 4.11$ & $91.75 \pm 4.74$ \\
\hline Min. & 19.6 & 15.5 & 15.5 & 46.94 & 17.64 & 17.64 \\
\hline \multirow[t]{2}{*}{ Max. } & 31.2 & 29.0 & 31.2 & 229.87 & 154.92 & 229.87 \\
\hline & & $P<0.05$ & & & $P<0.05$ & \\
\hline
\end{tabular}

The length-frequency distributions of the females, males, and all individuals were determined (Fig. 2). The mean value of total length and weight were $25.49 \pm 0.517 \mathrm{~cm}$ and $115.42 \pm 8.01 \mathrm{~g}$ for females, $22.18 \pm 0.378 \mathrm{~cm}$ and $73.62 \pm 4.11 \mathrm{~g}$ for males, $23.6 \pm 0.358 \mathrm{~cm}$ and $91.75 \pm 4.74 \mathrm{~g}$ for all individuals, respectively. The weight distributions were 46.94-229.87 $\mathrm{g}$ for females, 17.64-154.92 $\mathrm{g}$ for males and 17.64-229.87 $\mathrm{g}$ for all individuals (Fig. 2). The length distributions were 19.60-31.20 cm for females, $15.50-29.00 \mathrm{~cm}$ for males and $15.50-31.20 \mathrm{~cm}$ for all individuals.
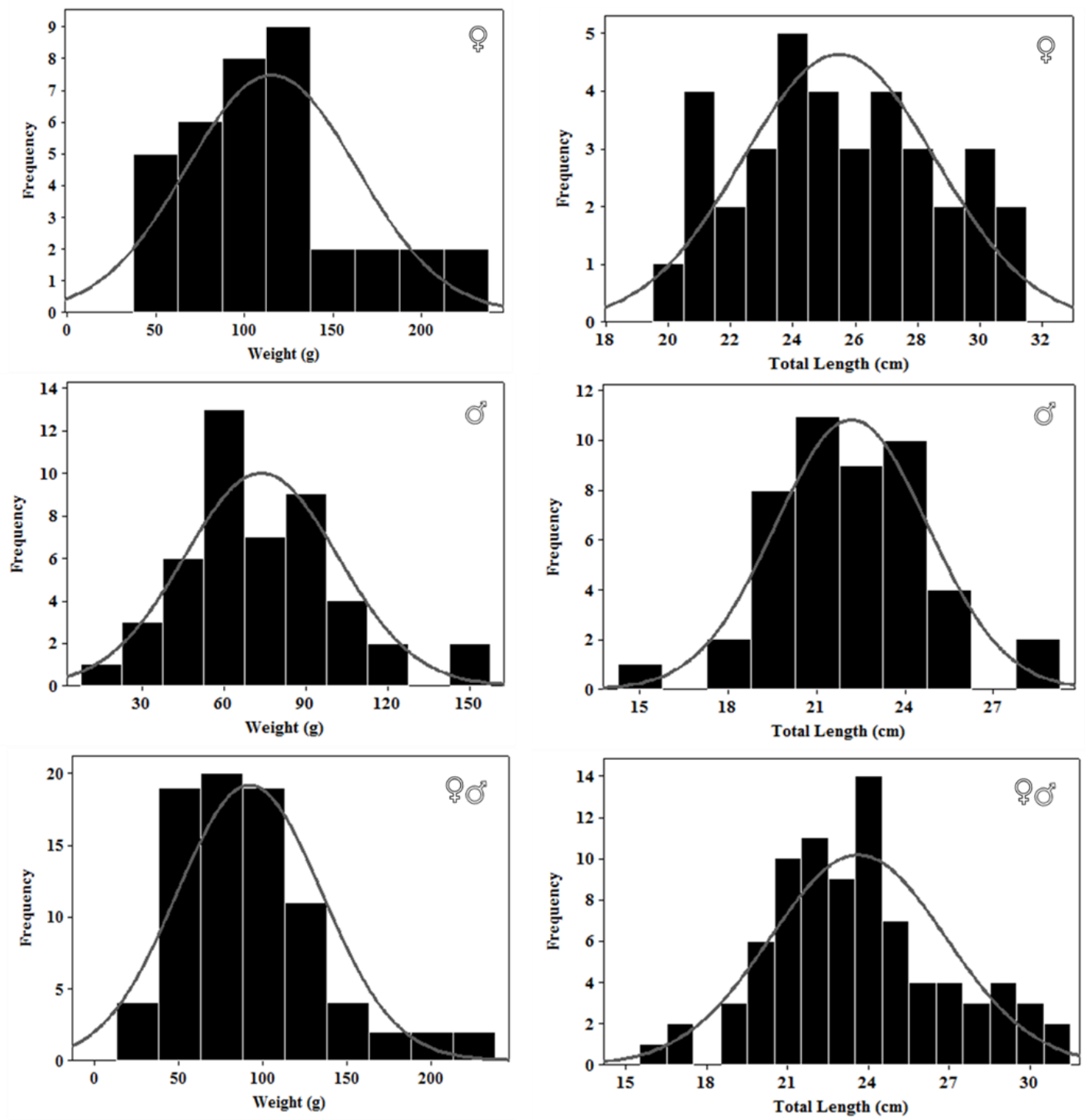

Figure. 2. The weight-frequency and length-frequency distribution graphs for females, males, and individuals of $S$. undosquamis from İskenderun Bay 
In the present study, the length-weight relationship was estimated separately for males, females and all individuals. The " $b$ " values were $3.3309,3.4874$ and 3.3667 for female, male and pooled sexes, respectively (Fig. 3). The value was found within the expected range of 2.5-3.5 which was described by Froese (2006) and in all the cases the LWRs were significantly important $\left(P<0.001, \mathrm{r}^{2}>0.990\right.$, Table 2).

The brushtooth lizardfish LWR " $b$ " value was found to be significantly different $(P<0.05)$ and the growth type was positive allometric for female, male and all individuals (Table 2).

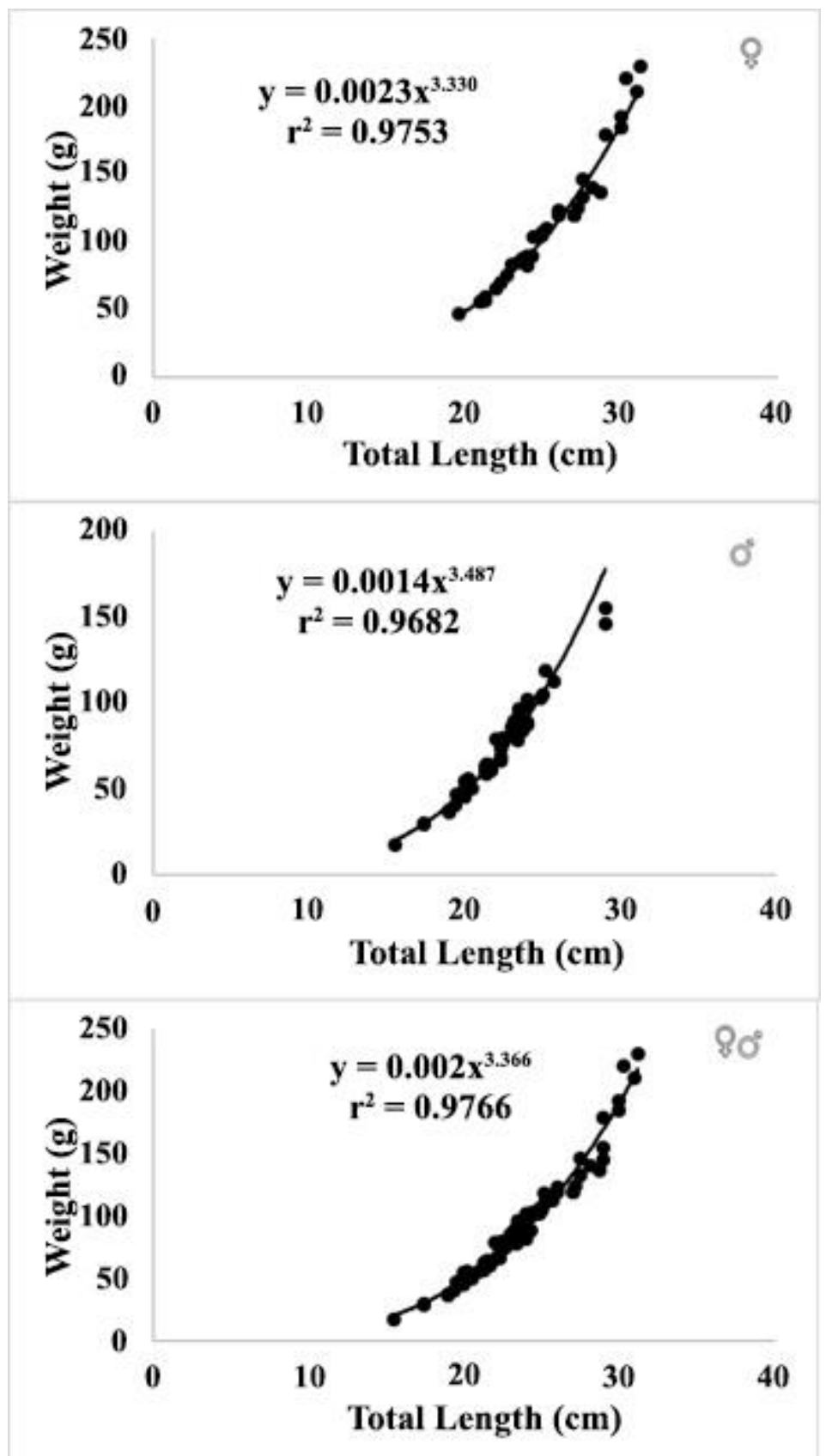

Figure. 3. The length-weight relationship for females, males and all individuals of $S$. undosquamis from İskenderun Bay 
Length-Length and Length-Weight Relationships of Lessepsian Saurida undosquamis from the İskenderun Bay (Eastern Mediterranean, Turkey)

Table 2. LWR parameters and growth types for $S$. undosquamis from İskenderun Bay

\begin{tabular}{lccccc}
\hline & $\boldsymbol{a}$ & $\boldsymbol{b}$ & $\mathbf{r}^{\mathbf{2}}$ & $\mathbf{9 5 \%}$ Confidence Interval & Growth Type \\
\hline+ & 0.0023 & 3.330 & 0.975 & $3.146-3.515$ & Allometry + \\
\hline & 0.0014 & 3.487 & 0.968 & $3.297-3.677$ & Allometry + \\
†ิ & 0.0020 & 3.366 & 0.976 & $3.251-3.481$ & Allometry + \\
\hline
\end{tabular}

S. undosquamis length-length relationship equations and their coefficient of determinations were presented for the female, male and all individuals in Table 3. When the literature examined many studies found about LWR of the S. undosquamis (Table 4).

Table 3. Length-length relationships equations with coefficients for $S$. undosquamis from İskenderun Bay

\begin{tabular}{cc}
\hline \multicolumn{1}{c}{ Equations } \\
\hline \multirow{2}{*}{$\mathrm{TL}=1.0830 \mathrm{FL}+0.0686\left(\mathrm{r}^{2}=0.98\right)$} \\
& $\mathrm{TL}=1.1414 \mathrm{SL}+0.2565\left(\mathrm{r}^{2}=0.98\right)$ \\
\hline \multirow{3}{*}{$+\mathrm{FL}^{2}=1.0491 \mathrm{SL}+0.281\left(\mathrm{r}^{2}=0.99\right)$} \\
\hline
\end{tabular}

As a result, the number of factors that affect the differences in the $b$ value is quite high. The feeding and the habitat types of the fishes are adjustable factors (Bostanci et al., 2017). Along with this, differences between geographic regions, sample size, and similar factors may also cause this value to change (Bagenal and Tesch, 1978). Indeed, the difference shown in Table 4 makes the effect of geographic region difference on the $b$ parameter clear. In fact, the $b$ value differences of the species in Table 4 clearly shows the effect of geographic region differences on the $b$ parameter.

Table 4. Comparison of length-weight relationships of S. undosquamis with previous studies

\begin{tabular}{llccc}
\hline References & Locality & n & $\begin{array}{c}\text { Relationship } \\
\text { equations }\end{array}$ & $\begin{array}{c}\mathbf{r}^{2} \\
\text { (n) }\end{array}$ \\
\hline Rao, 1983 & India & 312 & $\mathrm{~W}=0.005811 \mathrm{~L}^{3.0308}$ & $*$ \\
Can et al., 2002 & İskenderun Bay, South coast & 100 & $\mathrm{~W}=0.0117 \mathrm{~L}^{2.7971}$ & 0.900 \\
Abdallah, 2002 & Alexandria, Egypt & 465 & $\mathrm{~W}=0.003 \mathrm{~L}^{3.30}$ & 0.953 \\
Rajkumar et al., 2003 & Visakhapatnam, India & 466 & $\mathrm{~W}=0.000003 \mathrm{~L}^{3.102}$ & $*$ \\
Çiçek et al., 2006 & Babadillimani Bight N-E Mediterranean Turkish coast & 1801 & $\mathrm{~W}=0.039 \mathrm{~L}^{3.165}$ & 0.968 \\
Sangun et al., 2007 & North-Eastern Mediterranean, Turkey & 416 & $\mathrm{~W}=0.0039 \mathrm{~L}^{3.159}$ & 0.960 \\
Ceyhan et al., 2009 & Gökova Bay, (Aegean Sea) Turkey & 80 & $\mathrm{~W}=0.0046 \mathrm{~L}^{3.109}$ & 0.951 \\
Gökçe et al., 2010 & İskenderun Bay, Turkey & 79 & $\mathrm{~W}=0.0105 \mathrm{~L}^{2.80}$ & 0.940 \\
Wang et al., 2012 & Northern South, China Sea & 7442 & $\mathrm{~W}=0.956 \mathrm{~L}^{3.043}$ & 0.999 \\
Kalhoro et al., 2014 & Pakistan & 870 & $\mathrm{~W}=0.008 \mathrm{~L}^{3.000}$ & 0.965 \\
Chhandaprajnadarsini et al., 2018 & Mumbai, India & 280 & $\mathrm{~W}=0.006 \mathrm{~L}^{2.99}$ & 0.904 \\
This study & İskenderun Bay, Turkey & 110 & $\mathrm{~W}=0.002 \mathrm{~L}^{3.366}$ & 0.976 \\
\hline
\end{tabular}

*unspecified data

When the $b$ values of $S$. undosquamis inhabited in different habitats are compared, it is seen that $b$ value is between 2.797 and 3.366. The $b$ value was calculated as a 2.797 for the same species in December 2000 in the İskenderun Bay (Can et al., 2002). However, in the current study, the $b$ value was calculated as 3.366 for S. undosquamis from İskenderun Bay in April 2009. Although there were 
examined the same habitat and the same species, two different $b$ values were determined. The main reasons can be differences in the sample sizes and sampling periods. Because the study was conducted by Can et al. (2002) in December 2000 and their sample size distribution is $17.40-33.10 \mathrm{~cm}$, and we sampled the fish in April 2009 and the sample size distribution is $15.50-32.20 \mathrm{~cm}$.

\section{CONCLUSION}

Stock assessments provide the important scientific information necessary for the management and conservation of fish stocks. Therefore, it is necessary to continuously monitor the natural stocks by ensuring the sustainability of fish stocks. The length-weight, length-length relationships and condition factor in fish are not constant but may vary depending on several factors such as nutritional adequacy, gonad development, nutrition rate and reproductive periods. The parameters also may vary among species and population depending on many factors, such as genetic structure, body shape, and condition factor. In addition, the number of samples, length-weight distributions, sampling periods and the ecological conditions of the habitats may have caused these differences. Therefore, in future studies, it is also important to examine the same species in different habitats or in individuals of different lengthweight distributions. Continuous monitoring of natural stocks for sustainable ecosystem management is also extremely important in terms of fishing biology and management. The present study has provided baseline information on LLRs and LWRs which could be useful for subsequent bioecological and population-based studies on S. undosquamis.

\section{REFERENCES}

Abdallah M, 2002. Length-weight relationship of fishes caught by trawl off Alexandria, Egypt. Naga. The Iclarm $\mathrm{Q}, 25:$ 19-20.

Bagenal TB, Tesch FW, 1978. Age and Growth. In T. Bagenal (Ed), Methods for assessment of fish production in fresh waters, 3rd ed: IBP Handbook No.3, Blackwell Science Publications, Oxford.

Bilecenoğlu M, Alfaya J, Azzurro E, Baldacconi R, Boyaci Y, Circosta V, Compagno L, Coppola F, Deidun A, Durgham H, Durucan F, Ergüden D, Fernández-Álvarez F, Gianguzza P, Giglio G, Gökoğlu M, Gürlek M, Ikhtiyar S, Kabasakal H, Karachle P, Katsanevakis S, Koutsogiannopoulos D, Lanfranco E, Micarelli P, Özvarol Y, Pena-Rivas L, Poursanidis D, Saliba J, Sperone E, Tibullo D, Tiralongo F, Tripepi S, Turan C, Vella P, Yokeş M, Zava B, 2013. New Mediterranean Marine biodiversity records (December, 2013). Mediterranean Marine Science, 14(2): 463-480.

Bostanci D, Yedier S, Kontaş S, Kurucu G, Polat N, 2017. Length-weight, length-length relationships and condition factors of some fish species in Yalıköy Stream (Ordu-Turkey). Aquaculture Studies, 17: 375-383.

Can F, Başusta N, Çekiç M, 2002. Weight length relationship for selected fish species of the small scale fisheries off the South coast of İskenderun Bay. Turkish Journal of Veterinary \& Animal Sciences, 26: 1181-1183.

Ceyhan T, Akyol O, Erdem M, 2009. Length weight relationship of fishes from Gökova Bay, Turkey (Aegean Sea). Turkish Journal of Zoology, 33: 69-72.

Chhandaprajnadarsini EM, Roul SK, Swain S, Jaiswar AK, Shenoy L, Chakraborty SK, 2018. Biometric analysis of brushtooth lizard fish Saurida undosquamis (Richardson, 1848) from Mumbai waters. Journal of Entomology and Zoology Studies, 6 (2): 1165-1171.

Çicek E, Avşar D, Yeldan H, Özütok M, 2006. Length-weight relationships for 31 teleost fishes caught by bottom trawl net in the Babadillimani Bight (Northeastern Mediterranean). Journal of Applied Ichthyology, 22(4): 290-292.

Froese R, 2006. Cube law, condition factor and weight-length relationships: History, meta-analysis and recommendations. Journal of Applied Ichthyology, 22: 241-253.

Froese R, Pauly D, 1998. Fishbase 1998: concepts, design and data sources. ICLARM, Manila. 
Froese R, Pauly D, 2019. Fishbase. World Wide Web Electronic Publication, www.fishbase.org. Accessed 12 February 2019.

Gökçe G, Çekiçi M, Filiz H, 2010. Length weight relationship of marine fishes off Yumurtalik coast (İskenderun Bay), Turkey. Turkish Journal of Zoology, 34: 101-104.

Golani D, 1998. Distribution of Lessepsian migrant fish in the Mediterranean. Italian Journal of Zoology, 65: 9599.

Kadharsha K, Mohanchander P, Lyla PS, Khan SA, 2013. Feeding and Reproductive Biology of Saurida undosquamis (Richardson, 1848) from Parangipettai Coast, Southeast Coast of India. Pakistan Journal of Biological Science, 16: 1479-1487.

Kalhoro MA, Liu Q, Waryani B, Panhwar SK, Memon KH, 2014. Growth and mortality of brushtooth lizardfish, Saurida undosquamis, from Pakistani Waters. Pakistan Journal of Zoology, 46(1): 139-151.

Özpiçak M, Saygın S, Hançer E, Aydın A, Yılmaz S, Polat N, 2018. Length-weight and length-length relationships of chub (Squalius cephalus, L., 1758) inhabiting a few inland waters of the Middle Black Sea Region. Ege Journal Fisheries and Aquatic Sciences, 35(2): 175-179.

Petrakis G, Stergiou K, 1995. Weight-length relationships for 33 fish species in Greek waters. Fisheries Research, 21(3): 465-469.

Rajkumar U, Sivakami S, Rao KN, Kingsly HJ, 2003. Lizardfish fishery, biology and population dynamics of Saurida undosquamis (Richardson) off Visakhapatnam. Indian Journal of Fisheries, 50: 149-156.

Rao KVS, 1983. Length-weight relationship in Saurida tumbil and S. undosquamis and relative condition in $S$. tumbil. Indian Journal of Fisheries, 30(2): 296-305.

Ricker WE, 1975. Computation and interpretation of biological statistics of fish populations. Bulletin of the Fisheries Research Board of Canada 191, 382 p, Ottawa, Canada.

Sangun L, Akamca E, Akar M, 2007. Weight length relationship for 39 fish species from North-Eastern Mediterranean Coast of Turkey. Turkish Journal of Fisheries and Aquatic Sciences, 7: 37-40.

Saygın S, Özpiçak M, Aydın A, Hançer E, Yılmaz S, Polat N, 2018. Length-weight and length-length relationships of the European bitterling, Rhodeus amarus (Bloch, 1782) inhabiting inland waters of Samsun Province. BAUN Fen Bilimleri Enstitü Dergisi, 20(2): 201-210.

Sulak KJ, 1986. Synodontidae. In: P.J.P. Whitehead, M.L. Bauchot, J.C. Hureau, J. Nielsen and E. Tortonese (eds.): Fishes of the North-eastern Atlantic and the Mediterranean, Vol. I, 405-411 pp. UNESCO, Paris.

Türker D, Bal H, 2018. Length-weight relationships of 13 fish species from the western Black Sea (ZonguldakAmasra), Turkey. J. Black Sea/Mediterranean Environment, 24(2):115-127.

Türker D, Zengin K, Tünay ÖK, 2019. Length-weight relationships for nine chondrichthyes fish species from Edremit Bay (North Aegean Sea). Turkish Journal of Fisheries and Aquatic Sciences, 19(1):71-79.

Wang X, Qiu Y, Du F, Lin Z, Sun D, 2012. Population parameters and dynamic pool models of commercial fishes in the Beibu Gulf, northern South China Sea. Chinese Journal of Oceanology and Limnology, 30: 105-117.

Yazıcığlu O, Yılmaz S, Yazıcı R, Polat N, 2013. Condition factor, length-weight and length-length relationships of Prussian carp, Carassius gibelio (Bloch, 1782) inhabiting Lake Ladik, Samsun, Turkey. Karadeniz Fen Bilimleri Dergisi, 3: 72-80.

Yedier S, Kontaş, S, Bostancı D, 2019. Marmara denizi'nde yaşayan Pagellus acarne (Risso, 1827)'nin kondisyon faktörü, boy-boy ve boy-ağırlık ilişkileri. Journal of Anatolian Environmental and Animal Sciences, 4: 8288.

Yılmaz S, Yazıcıoğlu O, Yılmaz M, Polat N, 2010. Hirfanlı Baraj Gölü'nde yaşayan Cyprinus carpio L., 1758 ve Tinca tinca (L., 1758)'nın boy-ağırlık ve boy-boy ilişkileri ile mevsimsel kondisyon faktörleri. SDU Journal of Science (E-Journal), 5: 154-162.

Yılmaz S, Yazıcıoğlu O, Erbaşaran M, Esen S, Zengin M, Polat N, 2012. Length-weight relationship and relative condition factor of white bream, Blicca bjoerkna (L., 1758), from Lake Ladik, Turkey. Journal of Black Sea/Mediterranean Environment, 18: 380-387. 